\title{
OVARIAN SUPPORT OF PREGNANCY IN AGEING INBRED MICE
}

\author{
R. G. GOSDEN* \\ Physiological Laboratory, Downing Street, Cambridge CB2 $3 E G$
}

(Received 29th May 1974)

\begin{abstract}
Summary. The principal cause of reduced fertility in 10- to 12-monthold female CBA/H-T6 and CBA mice was found to be loss of embryos at the time of, or soon after, implantation. Treatment with exogenous progesterone, but not with oestradiol benzoate, increased the number of old females having implantation sites but did not increase either the average number of implantations/female or postimplantation survival to Day 10 . When bovine prolactin or HCG was administered to pregnant old mice, the implantation rate was not increased. It was concluded that the function of the CL of pregnancy in old mice may have been impaired because the lutein cells were failing to respond adequately to the luteotrophic stimulus.
\end{abstract}

\section{INTRODUCTION}

The average litter size of female mice declines with increasing age and breeding ceases well before the end of the life-span (Talbert, 1968). This reduced fertility of old mice cannot be attributed to a decline in ovulation rate since the number of CL of pregnancy remain high (Biggers, Finn \& McLaren, 1962; Harman \& Talbert, 1970). Embryonic losses caused by failure of fertilization and preimplantation development in ageing GBA/H-T6 mice appear to be small (Gosden, 1973a), suggesting that most of the prenatal mortality occurs at or soon after the time of implantation. It has been shown that these losses are not primarily due to defects of the ova (Talbert \& Krohn, 1966; Gosden, 1973a, 1974a). Pregnancy failure may be caused by insufficient luteal activity for there is an association between degenerative changes in the CL of old mice on Day 7 of pregnancy and the failure of implantation (Harman \& Talbert, 1970).

In the present study, the effects of exogenous gonadal and gonadotrophic hormones on the pregnancies of ageing mice were examined to determine whether the ovarian function is impaired in old age and, if so, in what way it is impaired.

\section{MATERIALS AND METHODS}

Inbred $\mathrm{CBA} / \mathrm{H}-\mathrm{T} 6$ and $\mathrm{CBA}$ mice from the laboratory colony were used. Females of various ages (see below) were mated by fertile males and were placed in individual cages on the day a copulatory plug was found (Day 1). * Present address: Department of Anatomy, Duke University, Medical Genter, Durham, N.C. 27710, U.S.A. 
Hormones were administered subcutaneously in $0.05 \mathrm{ml}$ arachis oil (progesterone and oestrogen) or saline (gonadotrophin) at 12.00 hours. Females were killed on Day 7 or Day 10 of pregnancy.

The uteri were dissected and examined. Horns lacking visible implantation sites were flushed with isotonic saline before fixation and the flushings were examined for ova under a stereomicroscope. All uteri were trimmed free of mesenteries, fixed, bleached, dehydrated and cleared in benzyl benzoate for counting and examination of the implanted embryos (Orsini, 1962). When required, the two maximum diameters of the decidual capsules in the cleared uteri were measured at right angles to each other under a stereomicroscope with a fitted eye-piece micrometer. The mean radius ( $r$ ) was calculated and the spherical volume of the decidual capsules was derived from the formula, $4 / 3 \pi \mathrm{r}^{3}$.

The ovaries of some females were removed and the CL were identified and counted under a stereomicroscope. Some ovaries were subsequently prepared histologically as serial sections after fixation in Bouin's fluid, embedding in paraffin wax, sectioning at $7 \mu \mathrm{m}$ and staining with Mayer's haemalum and eosin.

Experimental results were evaluated statistically by Fisher's exact test of probability, analysis of variance and Student's $t$ test.

\section{Experiment 1}

Thirty-four CBA/H-T6 female mice, of different ages and mostly multiparous except for the youngest animals, were removed from the breeding colony and killed on Day 4 of pregnancy. Eight 10- to 12-month-old primigravid females were killed at the same stage of pregnancy and the numbers of CL were compared.

\section{Experiment 2}

Mice of three types (see Table 1) were mated by males of their own strain and were randomly allocated to one of four groups in which they received $0.0,0.25,0.50$ or $1.00 \mathrm{mg}$ progesterone (Koch-Light)/day from Day 2 to Day 9. The animals were killed on Day 10 and the numbers of live and resorbing embryos were determined.

\section{Experiment 3}

The effects of oestrogen and progesterone were studied using a $2 \times 2$ factorial design (Table 2). Virgin CBA mice (10 to 11 months old), which had mated with $\mathrm{F}_{1}$ hybrid (C57BL $\times \mathrm{A}_{2} \mathrm{G}$ ) males, received one of the following treatments: (1) $1 \mathrm{mg}$ progesterone/day from Day 2 to Day 9 ; (2) $0.05 \mu \mathrm{g}$ oestradiol-17 $\beta$ benzoate (Koch-Light)/day from Day 4 to Day 9 ; (3) oestrogen and progesterone as in (1) and (2) above; (4) the vehicle alone. Autopsy was on Day 10.

\section{Experiment 4}

Virgin CBA mice (10 to 11 months old) were mated by $F_{1}$ hybrid (G57BL $\times$ $\left.A_{2} G\right)$ males and were injected morning and evening from Day 1 to Day 6 with (1) 5 i.u. bovine prolactin (NIH-P-B3), (2) 5 i.u. HCG (Organon) or (3) saline only, or were treated with $1 \mathrm{mg}$ progesterone/day from Day 2. 
Young females ( 2 to 3 months old) were also injected with saline only. The animals were killed on Day 7, and the number and size of the implantation sites was recorded.

\section{Experiment 1}

\section{RESULTS}

The number of CL in the parous mice increased until the animals were about 9 months old (Text-fig. $1 ; r=0.422, P<0.01$, slope $=0.384$ ). The old primigravid females had the same number of CL as did young females, but fewer than did multiparae of similar age (Text-fig. 1). In the ovaries of onethird of the ageing CBA mice, but not in those of young animals, oocytes had

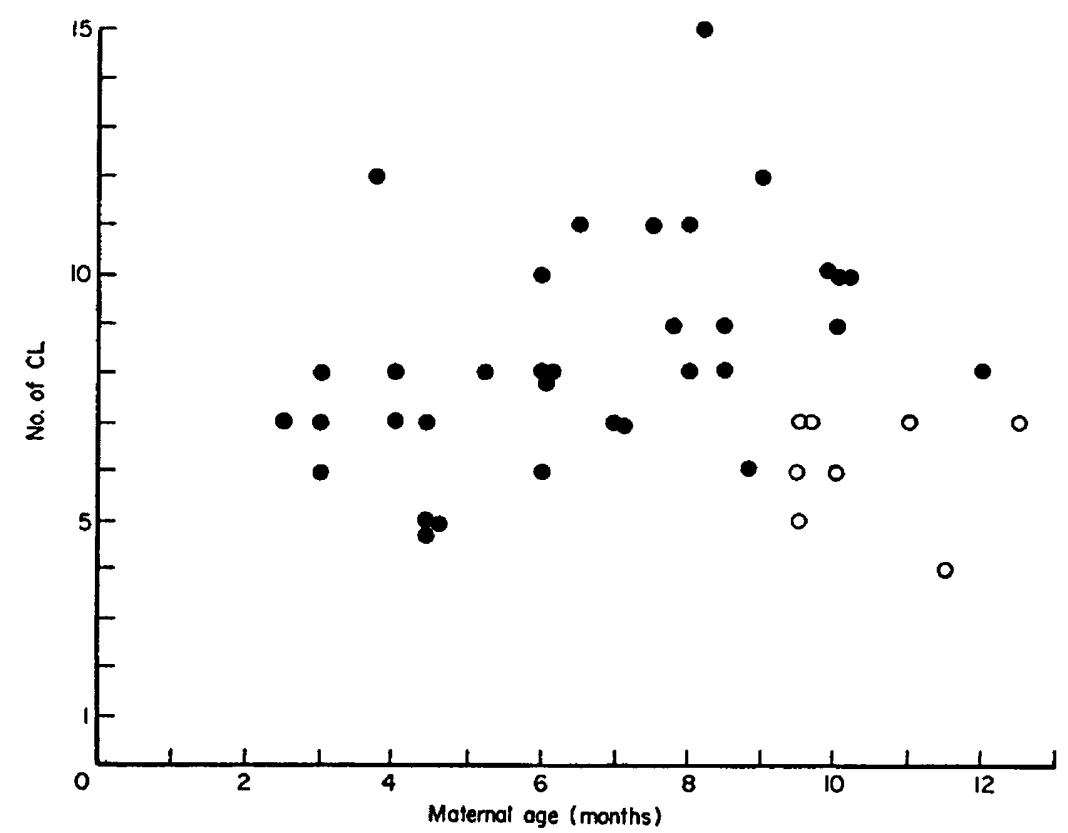

TExT-Fic. 1. The number of corpora lutea in pregnant mice of different ages. $\bullet$, Animals from the breeding colony, i.e. multiparous, except for the youngest animals; $O$, old primigravid females.

been retained within histologically normal CL (corpora lutea accessoria). This could have lead to bias in estimating the ovulation rate from macroscopic CL counts but the effect was probably small, since only one to three of these were present in individual animals.

\section{Experiment 2}

Many of the old mice, whether primi- or multigravidae, had no visible implantation sites on Day 10 (Table 1). The proportion with implantations was significantly increased by treatment with $0.5 \mathrm{mg}$ or more of progesterone, and progesterone treatment increased the numbers of implantation sites/pregnancy in the old primigravid females in this experiment $(P<0.05)$ but not in those 
of Exps 3 and 4. There were more resorbing embryos in the older females but survival to Day was not affected by treatment with progesterone.

No free blastocysts were found in the uterine flushings of these 10-day pregnant mice without implantation sites but two blastocysts, each containing more than seventy-two nuclei, were recovered at Day 9 from an old mouse in a pilot experiment.

\section{Experiment 3}

The effects of oestrogen and progesterone are shown in Table 2. Progesterone was found to have a significant effect but the oestrogen effect was not significant.

Table 1. The effect of progesterone on implantation in mice of different ages and reproductive history

\begin{tabular}{|c|c|c|c|c|c|c|c|}
\hline \multicolumn{2}{|c|}{$\begin{array}{c}\text { Type of mou } \\
\text { Strain }\end{array}$} & \multirow{2}{*}{$\frac{\begin{array}{c}\text { Age } \\
\text { (months) }\end{array}}{10 \text { to } 11}$} & \multirow{2}{*}{$\begin{array}{c}\begin{array}{c}\text { Progesterone dose } \\
\text { (mg/day })\end{array} \\
0 \\
0.25 \\
0.50 \\
1.00\end{array}$} & \multirow{2}{*}{$\begin{array}{c}\text { No. of mice } \\
\\
9 \\
10 \\
10 \\
10\end{array}$} & \multirow{2}{*}{$\begin{array}{c}\begin{array}{c}\text { No. pregnant* } \\
(\%)\end{array} \\
2(22) \\
6(60) \\
9(90) \dagger \\
9(90) \dagger\end{array}$} & \multicolumn{2}{|c|}{ 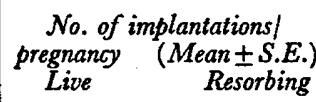 } \\
\hline CBA/H-T6 & 0 & & & & & $\begin{array}{l}1.0 \pm 1.0 \\
2.5 \pm 1.1 \\
2.6 \pm 0.6 \\
2.9 \pm 0.7\end{array}$ & $\begin{array}{l}2.0 \pm 0 \\
3.7 \pm 0.6 \\
2.8 \pm 0.5 \\
3.0 \pm 0.7\end{array}$ \\
\hline $\mathrm{CBA} / \mathrm{H}-\mathrm{T} 6$ & 0 & 2 to 3 & $\begin{array}{l}0 \\
1 \cdot 00\end{array}$ & $\begin{array}{l}10 \\
10\end{array}$ & $\begin{array}{l}8(80) \\
9(90)\end{array}$ & $\begin{array}{l}6.3 \pm 0.4 \\
5.8 \pm 0.9\end{array}$ & $\begin{array}{l}1.4 \pm 0.5 \\
1.3 \pm 0.5\end{array}$ \\
\hline CBA & $>1$ & 11 to 12 & $\begin{array}{l}0 \\
1 \cdot 00\end{array}$ & $\begin{array}{l}11 \\
10\end{array}$ & $\begin{array}{l}4(36) \\
9(90) \ddagger\end{array}$ & $\begin{array}{l}1 \cdot 8 \pm 1 \cdot 0 \\
3 \cdot 1 \pm 1 \cdot 3\end{array}$ & $\begin{array}{l}3.0 \pm 0.7 \\
2 \cdot 7 \pm 0.6\end{array}$ \\
\hline
\end{tabular}

* At Day 10.

+ Significantly different from control, $P=0.0049$.

$\$$ Significantly different from control, $P=0.017$.

Table 2. Effects of exogenous ovarian hormones on implantation in old mice

\begin{tabular}{l|c|c|c}
\hline \multicolumn{1}{c|}{ Treatment } & $\begin{array}{c}\text { No. of } \\
\text { animals }\end{array}$ & $\begin{array}{c}\text { No. pregnant } \\
(\%)\end{array}$ & $\begin{array}{c}\text { No. of implantations/ } \\
\text { pregnancy }(\text { Mean } \pm \text { S.E. })\end{array}$ \\
\hline Oil (control) & 12 & $9(75)$ & $8 \cdot 1 \pm 0.9$ \\
Progesterone & 11 & $11(100)^{*}$ & $7 \cdot 4 \pm 0 \cdot 7$ \\
Progesterone+oestradiol benzoate & 11 & $9(82)^{*}$ & $6.9 \pm 0.9$ \\
Oestradiol benzoate & 12 & $7(58)$ & $5 \cdot 3 \pm 1 \cdot 1$ \\
\hline
\end{tabular}

* $P=0.049$ when compared to animals not treated with progesterone.

\section{Experiment 4}

Exogenous prolactin and HCG, unlike exogenous progesterone, did not increase the proportion of old females bearing implantations (Table 3). The volume of the decidual capsules on Day 7 was smaller in old mice than in young mice $(P<0.001)$ and was not affected by hormone treatment. In contrast to the results for the GBA/H-T6 mice (Text-fig. 1), young CBA mice had significantly more CL than did the old primigravidae.

In these experiments, the use of either inbred or hybrid males made no apparent difference to the results. 


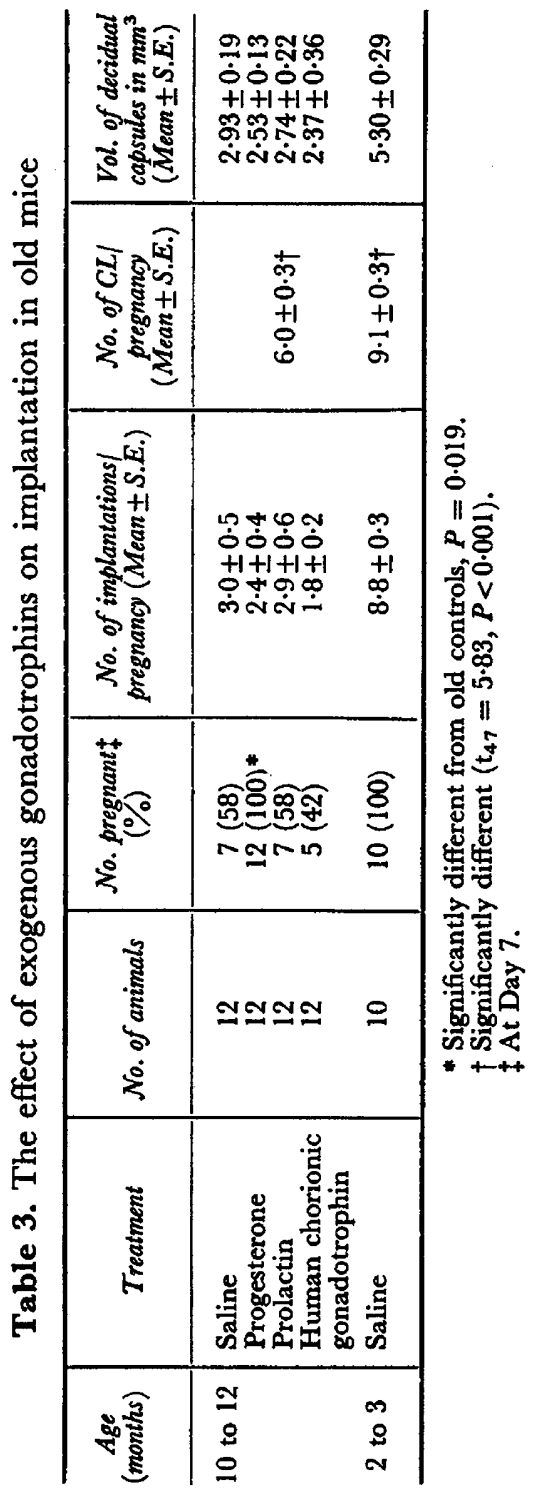




\section{DISCUSSION}

The maternal factors that are responsible for the increased prenatal mortality of embryos in ageing mice are still unclear. The gametogenic function of the ovary is maintained for some time after the onset of infertility in senescent mice, although there is a well-documented increase in ovulation failure due to the failure of follicle rupture (Thung, 1958; Jones \& Krohn, 1961). The qualitative changes that have been observed in the GL of old mice on Day 7 indicate that a progesterone deficiency may cause pregnancy failure in these animals (Harman \& Talbert, 1970), although such changes could be a result of pregnancy loss (Talbert, 1971), and the histological assessment of luteal function is not reliable (Finn, 1970). The effect of exogenous progesterone found in the present experiments, and the earlier finding that older CBA/H-T6 mice have smaller lutein cells and, consequently, smaller CL on Day 4 (Gosden, 1974b), support the observations of Harman \& Talbert (1970) and indicate that CL function may be deficient before the onset of implantation. The lack of a salutary effect of exogenous oestrogen on implantation in old mice suggests that the effect of progesterone was not due to contamination by oestrogen. The smaller number of implantations in mice treated with $0.05 \mu \mathrm{g}$ oestradiol benzoate suggests that oestrogen treatment may actually be detrimental.

Several workers have found no evidence of impaired luteal function in aged animals. Embryonic survival was not increased in pregnant old mice by ligating one oviduct and improving the CL:embryo ratio (Finn, 1963) or by giving orthotopic ovarian grafts from young mice (Krohn, 1966). Measurements of plasma progestins in the hamster (Blaha, 1971) and in the rabbit (Spilman, Larson, Concannon \& Foote, 1972) have shown that hormone levels are similar in young and old animals, except when there were no viable fetuses late in pregnancy (Spilman et al., 1972), and supplementary progesterone and oestrogen did not increase embryonic survival in old rabbits (Larson, Spilman, Dunn \& Foote, 1973). There is, however, some evidence of luteal deficiency in older women. Basal body temperature measurements have shown that the hyperthermic phase of the menstrual cycle is less marked and less regular in length in women over 39 and under 25 years of age (Collett, Wertenberger \& Fiske, 1954; Döring, 1969).

Sub-optimal levels of circulating progesterone in mouse pregnancy could cause the increased pregnancy loss characteristic of old age by failing to prepare the endometrium adequately for implantation and by failing to maintain the decidua. The present results are not incompatible, however, with a situation in which progesterone levels are normal but the binding of progesterone is impaired. Plasma progesterone must now be measured in ageing mice to examine luteal function by a more direct method.

Implantation also fails to occur in immature and ovariectomized pregnant mice and can be induced by treatment with exogenous progesterone (Smithberg \& Runner, 1956; McLaren, 1971). The parallel with old mice may not extend any further, however, since embryos are not usually present in the uterine flushings of old mice at mid-pregnancy and exogenous luteotrophic hormones will not restore a sufficient level of ovarian activity to induce implantation as 
they will in immature animals (Tessaro \& Runner, 1956). If progesterone secretion is in fact reduced, the lack of effect of luteotrophic hormones in pregnant old mice suggests that the lutein cells may be refractory to gonadotrophic stimulation. It has been suggested that the establishment of fewer placentae in senescent female hamsters might result in a reduced output of placental luteotrophin which would lead, ultimately, to postimplantation failure (Thorneycroft \& Soderwall, 1968). This hypothesis seems unlikely to be correct for mice since daily supplementation with prolactin from Day 1 to Day 18 of pregnancy in aged C57BL mice did not affect the survival of embryos (Gosden, 1973b). The dose of prolactin used was known to make the uterus of young oestrous mice sensitive to decidualizing stimuli (R. G. Gosden, unpublished results), and to restore fertility to pituitary dwarf mice (Bartke, 1966). Bindon \& Lamond (1969) also found that 10 i.u. HCG/day effectively maintained pregnancy in hypophysectomized mice. The negative results in the present experiments may, however, have been due to production of antihormones after administration of heterologous hormones. It is also possible that a combination of luteinizing and luteotrophic hormones would have been more effective than either given separately (Tessaro \& Runner, 1956; Browning, Larke \& White, 1962). Alternatively, FSH may be necessary for stimulation of the CL (Choudary \& Greenwald, 1969). Further experiments are needed to test these possibilities.

Extraovarian factors are almost certainly also operating to cause the agedependent loss of reproductive capacity. These factors may include intrinsic changes of the uterus because the decidual cell reaction is diminished with age in mice and hamsters and is not restored even when supplementary hormones are given (Finn, 1966; Blaha, 1967). The smaller size of decidual capsules in the old mice used in this study confirms these earlier observations. The present results have shown that postimplantation losses in senescent mice are not reduced by treatment with progesterone and are an indication of uterine deficiency in such mice.

\section{AGKNOWLEDGMENTS}

I wish to thank Dr R. G. Edwards for his advice and interest throughout this study, Professor C. R. Austin for critically reading the manuscript and Mrs Gilla Fuller for help with the manuscript. The prolactin was generously donated by the National Institute of Arthritis and Metabolic Diseases' Endocrinology Study Section. Financial support from the Medical Research Council and the Ford Foundation is gratefully acknowledged.

\section{REFERENGES}

Bartke, A. (1966) Reproduction of female dwarf mice treated with prolactin. F. Reprod. Fert. 11, 203-206.

Biggers, J. D., Finn, G. A. \& McLaren, A. (1962) Long-term reproductive performance of female mice. II. Variation of litter size with parity. F. Reprod. Fert. 3, 313-330.

Bindon, B. M. \& Lamond, D. R. (1969) Effect of hypophysectomy on implantation in the mouse. $\mathcal{F}$. Reprod. Fert. 18, 43-50.

BLAHA, G. C. (1967) Effects of age, treatment, and method of induction on deciduomata in the golden hamster. Fert. Steril. 18, 477-485. 
BLAHA, G. C. (1971) Ovarian steroid dehydrogenase and plasma progesterone levels in aged golden hamsters. Anat. Rec. 169, 279-280, Abstr.

BRowning, H. G., LARKe, G. A. \& WhITE, W. D. (1962) Action of purified gonadotropins on corpora lutea in the cyclic mouse. Proc. Soc. exp. Biol. Med. 111, 686-690.

Choudary, J. B. \& Greenwald, G. S. (1969) Luteotropic complex of the mouse. Anat. Rec. 163, 373-388.

Collett, M. E., Wertenzerger, G. E. \& Fiske, V. M. (1954) The effect of age upon the pattern of the menstrual cycle. Fert. Steril. 5, 437-448.

Döring, G. K. (1969) The incidence of anovular cycles in women. F. Reprod. Fert., Suppl. 6, 77-81.

FinN, C. A. (1963) Reproductive capacity and litter size in mice. Effect of age and environment. J. Reprod. Fert. 6, 205-214.

Fins, C. A. (1966) The initiation of the decidual cell reaction in the uterus of the aged mouse. $\mathcal{J}$. Reprod. Fert. 11, 423-428.

Fins, C. A. (1970) The ageing uterus and its influence on reproductive capacity. F. Reprod. Fert., Suppl. 12, 31-38.

Gosden, R. G. (1973a) Ghromosomal anomalies of preimplantation mouse embryos in relation to maternal age. F. Reprod. Fert. 35, 351-354.

Gospen, R. G. (1973b) Reproductive senescence in female rodents. Ph.D. thesis, University of Cambridge.

Gosden, R. G. (1974a) Survival of transferred C57BL mouse embryos: effect of age of donor and recipient. Fert. Steril. 25, 348-351.

Gosden, R. G. (1974b) Corpus luteum adequacy in the ageing pregnant mouse. Europ. f. Obstet. Gynec. Reprod. Biol., Suppl. 4, 109-111.

Harman, S. M. \& Talbert, G. B. (1970) The effect of maternal age on ovulation, corpora lutea of pregnancy and implantation failure in mice. F. Reprod. Fert. 23, 33-39.

JoNEs, E. G. \& KROHN, P. L. (1961) The relationships between age, numbers of oocytes and fertility in virgin and multiparous mice. F. Endocr. 21, 469-495.

KROHN, P. L. (1966) Transplantation and aging. In Topics in the Biology of Aging, pp. 125-139. Ed. P. L. Krohn. Wiley, Interscience, New York.

Larson, L. L., Spilman, C. H., Dunn, H. O. \& Foote, R. H. (1973) Reproductive efficiency in aged female rabbits given supplemental progesterone and oestradiol. F. Reprod. Fert. 33, 31-38.

MaLaren, A. (1971) Blastocysts in the mouse uterus: the effect of ovariectomy, progesterone and oestrogen. F. Endocr. 50, 515-526.

Orsini, M. W. (1962) Technique of preparation, study and photography of benzyl-benzoate cleared material for embryological studies. F. Reprod. Fert. 3, 283-287.

SmIthberg, M. \& RuNNER, M. N. (1956) The induction and maintenance of pregnancy in prepuberal mice. F. exp. Zool. 133, 441-457.

Spilman, G. H., Larson, L. L., Concannon, P. W. \& Foote, R. H. (1972) Ovarian function during pregnancy in young and aged rabbits: temporal relationship between fetal death and corpus luteum regression. Biol. Reprod. 7, 223-230.

TALBERT, G. B. (1968) Effect of maternal age on reproductive capacity. Am. F. Obstet. Gynec. 102, 451477.

TALBERT, G. B. (1971) Effect of maternal age on postimplantation reproductive failure in mice. $\mathcal{J}$. Reprod. Fert. 24, 449-452.

TALBERT, G. B. \& KROHN, P. L. (1966) Effect of maternal age on viability of ova and uterine support of pregnancy in mice. F. Reprod. Fert. 11, 399-406.

TEssaro, J. \& RunNer, M. N. (1956) Induction of pregnancy in prepuberal mice by means of gonadotropic hormones. Anat. Rec. 124, 371, Abstr.

ThorNeycroft, I. H. \& Soderwall, A. L. (1968) Antral follicle number and corpora lutea size changes during pregnancy in senescent hamsters. Fedn Proc. Fedn Am. Socs exp. Biol. 27, 739.

Thung, P. J. (1958) Ovaria van oude muizen. Thesis, University of Leiden, H. Born, Assen. 